\title{
Preface: Tears, Terror, and Wonder
}

\author{
Nathan Carlin ${ }^{1} \cdot$ Robert C. Dykstra ${ }^{2}$
}

Published online: 24 February 2018

(C) Springer Science+Business Media, LLC, part of Springer Nature 2018

Lewis Rambo, in his generosity, has continued to make space for papers written by participants in the Group for New Directions in Pastoral Theology; we remain indebted to him. Papers from previous conferences have been published in Pastoral Psychology in December 2010, June 2011, August 2012, October 2013, December 2014, October 2015, October 2016, and December 2016. This group has provided a venue for rigorous academic engagement as well as a space for regular fellowship and friendship among scholars in pastoral theology at various stages of their careers, including graduate students and retired professors.

The papers in this issue are from a gathering of the Group for New Directions in Pastoral Theology that met in Princeton, New Jersey, October 5-7, 2016. The theme for the gathering was "Tears, Terror, and Wonder: Facing the Anxieties of Everyday Life." It should be noted that there are fewer papers represented in this issue than were presented at the conference. This is because attendees are not required to write on the conference theme and so some choose to workshop drafts of papers for other purposes (e.g., dissertation chapters or parts of forthcoming books). This relaxed approach to the conference has worked well.

In an autobiographical chapter in The Faith and Friendships of Teenage Boys, Donald Capps (2012) recounts a poem he wrote in high school about the biblical story, in Luke 24, of two travelers on the road to Emmaus. In the poem, the adolescent Capps chooses the words tears, terror, and wonder to describe what the travelers experienced in talking with the stranger along the way, "words that, together," Capps writes, "convey the sense of an overwhelming mixture of emotions befitting the depth and enormity of the experience that they could not have anticipated in a thousand years" (p. 102). Later in his life, Capps reports increasingly coming to trust this childhood and adolescent self - the youthful poet who remained living within him - as a faithful, Emmaus-like companion whose wisdom and insights would guide him through the tears, terror, and wonder of facing middle and older adulthood.

Robert C. Dykstra

robert.dykstra@ptsem.edu

Nathan Carlin

nathanscarlin@gmail.com

$1 \quad$ McGovern Medical School, 6431 Fannin Street, JJL 410, Houston, TX 77030, USA

2 Princeton Theological Seminary, P.O. Box 821, Princeton, NJ 08542-0803, USA 
Inspired by these personal reflections, the papers in this issue take a closer look not only at the tears and terror of everyday life but also at various potential strategies and resources, however modest, for strengthening wonder and hope, individual or collective, that pastoral theologians might deploy in response. The five beautiful papers included here deal with student debt, immigration, life in "the ghetto," pressures from capitalism, and Korean woman who have been forced to serve as "comforters." There are many reasons for tears these days, for terror abounds, but fear and anxiety cannot have the last word. Hope must have the final word. And these authors give us reasons for hope, and they help us regain our much-needed sense of wonder.

\section{Reference}

Capps, D. (2012). Close friendships. In R. C. Dykstra, A. H. Cole, Jr. \& D. Capps (Eds.), The faith and friendships of teenage boys (pp. 87-106). Louisville: Westminster John Knox Press. 